\title{
Impact of tide gates on the migration of adult European eels, Anguilla anguilla
}

G.V. Wright ${ }^{\mathrm{a}^{*}}$, R.M. Wright ${ }^{* * *}$, P.S. Kemp ${ }^{\mathrm{a}^{* * *}}$

anternational Centre for Ecohydraulics Research, Faculty of Engineering and the Environment, University of Southampton, Highfield, Southampton, SO17 1BJ, UK

${ }^{b}$ Environment Agency, Rivers House, Threshelfords Business Park, Inworth Rd, Feering, CO5 9SE, UK

"Corresponding author: Tel: +44 (0)2380595386 E-mail: gvwright@outlook.com

${ }^{* *}$ E-mail: ros.wright@environment-agency.gov.uk

${ }^{* * *}$ E-mail: p.kemp@soton.ac.uk 


\begin{abstract}
Tide gates form a temporal barrier to fish migration, closing during the flood tide and opening during the ebb, primarily for flood prevention and land reclamation. Their impact on downstream adult migration of the critically endangered European eel, Anguilla anguilla, is unknown. The River Stiffkey, UK, has three top-hung tide gates (one counterbalanced, two not) through which it discharges into the North Sea. Adult eels of silver appearance $(n=118)$ were caught between 0.5 to $6.0 \mathrm{~km}$ upstream from the tide gates in Autumn 2011 and implanted with $23 \mathrm{~mm}$ half-duplex passive integrated transponder (PIT) tags. Tagged individuals were detected by PIT antennae located near the tide gates. Of the eels tagged, 80 were detected actively migrating downstream to the gates. Escapement past the gates was $98.3 \%$. Speed of migration was slower near the gates than for an unimpeded upstream reach, and was positively and negatively related to mean degree of gate opening and mean light intensity, respectively. When the largest gate was modified through installation of an orifice intended to improve upstream passage of sea trout and juvenile eels, downstream migration was more rapid when it was operating. However, video analysis revealed that eels did not pass through the orifice, meaning that faster migration may have been a result of the gates being open on more occasions when eels initially approached them, or the lower tides and upstream saline intrusion that occurred during these periods. Top-hung tide gates in the River Stiffkey delayed eel migration, potentially increasing the risk of predation and energy expenditure immediately prior to a 5000 - $6000 \mathrm{~km}$ migration to spawning grounds in the Sargasso Sea.
\end{abstract}

Keywords: silver eel, tide gate, escapement, passage efficiency, delay 


\section{Introduction}

European eel, Anguilla anguilla, recruitment has decreased by more than $90 \%$ since the early 1980 s (Dekker 2003; ICES 2012) leaving the species endangered (Freyhof and Kottelat 2008) and populations below sustainable conservation limits (Bult and Dekker 2007). A number of factors have been attributed to the decline, including variation in oceanic currents which reduce the rate of return (Baltazar-Soares et al. 2014) and food availability (Friedland et al. 2007) for leptocephali, and alter adult spawning location (Friedland et al. 2007); over harvest (Moriarty and Dekker 1997); pollution (Knights 1997; Robinet and Feunteun 2002); parasitism (Feunteun 2002), and impeded migration between essential habitats (Bruijs and Durif 2009; Laffaille et al. 2007; Winter et al. 2006). In an attempt to reverse this decline, the EU Eel Recovery Plan (2007) (Council Regulation No: $1100 / 2007 / E C$ ) requires that all Member States develop strategies to meet silver eel biomass escapement targets of $40 \%$ relative to that expected in the absence of anthropogenic impacts (EC 2007).

To date, eel escapement research has focused on: (1) assessing the barrier effects of structures on upstream migration of juveniles (Knights and White 1998; Piper et al. 2012), and (2) the impact of hydropower installations and success or failure of screening for downstream migrating adults (Calles et al. 2013; Calles et al. 2010; Pedersen et al. 2012; Russon et al. 2010). Intermittent barriers created by weirs, ramps, culverts, and tide gates, which are considerably more abundant than large structures such as dams (Lucas et al. 2009), have received less attention.

Tide gates temporally obstruct migrating fish by closing under hydraulic pressure on the flood tide, and opening during the ebb (Giannico and Souder 2005). Environmental conditions related to open gates, such as abrupt changes in salinity (Zaugg et al. 1985) and temperature (Berggren and Filardo 1993; Boyd and Tucker 1998; Jonsson 1991), accelerating water velocities (Haro et al. 1998; Russon and Kemp 2011a), continuous overhead cover created by associated culverts (Kemp et al. 2005a), and a lack of tidal cues (Russell et al. 1998) may cause stress and obstruct migration of some fish species. Although tide gates are used worldwide and are known to restrict fish species abundance and richness (Boys et al. 2012; Pollard and Hannan 1994), there has been little consideration of their impacts on the movement of diadromous fish, including eels. There are some exceptions. For example, fish passage is lower at gated culverts when compared to un-gated ones (for diadromous juvenile galaxiids, Doehring et al. 2011). Specifically regarding eels, tidal structures, such as manually operated intertidal sluices, have been related to increased entrainment loss of 
downstream migrating adult eels at an abstraction intake (Piper et al. 2013), while modifications to gates by maintaining connectivity through an aperture that remains open during the flood tide appear to enhance upstream abundance of glass eels (Mouton et al. 2011). The current lack of understanding of the impacts of tide gates on fish migration, including that for downstream moving eels, remains an area that requires further attention.

To date, the impact of tide gates on diadromous fish migrations are largely based on assumption or qualitative observation. Where fish passage is thought to be sufficiently restricted, top-hung tide gates may be replaced with side-hung or self-regulating designs, or modified with counterbalances, retarders, orifices, or slots, all of which extend the period of connectivity between upstream and downstream. The ability of these modifications to improve diadromous fish passage at tide gates, as well as their impact on important non-target species and life stages, has not been fully quantified elsewhere.

This study assessed the impact of top-hung tide gates on the escapement and delay of actively migrating adult European eels, and the influence of an orifice modification, installed to assist the upstream movement of adult sea trout and juvenile eels past the gates. PIT telemetry was used to: (1) determine eel escapement past the top-hung tide gate structure, (2) quantify delay by measuring speed through unimpeded (control) and tide gate (treatment) reaches, whilst (3) assessing the influence of environmental variables and the orifice modification in the River Stiffkey, UK.

\section{Materials and methods}

\subsection{Study site}

Fed by a $141 \mathrm{~km}^{2}$ catchment, the River Stiffkey, North Norfolk, UK ( $52^{\circ} 57^{\prime} \mathrm{N} ; 0^{\circ} 57^{\prime} \mathrm{E}$; Fig. 1) is sited on a chalk aquifer with a mean $( \pm S D$ ) daily flow (measured at Little Walsingham, $12.6 \mathrm{~km}$ upstream from the tide gates, over the study period from 23 September to 10 December 2011) of $0.09( \pm 0.02)$ $\mathrm{m}^{3} \mathrm{~s}^{-1}$. From its source at Swanton Novers the river flows north for $33 \mathrm{~km}$ through the Stiffkey Valley Site of Special Scientific Interest before discharging via tide gates into the Blakeney Channel and the North Sea. Tide Gate 1 (Fig. 2) is a top-hung design (width = $3.0 \mathrm{~m}$, height $=2.1 \mathrm{~m}$ ) opening at the seaward end of a corrugated metal pipe culvert (diameter $=2.9 \mathrm{~m}$, length $=25.8 \mathrm{~m}$ ). Located at the end of the main river channel, it discharges the majority of the river's flow (Fig. 1). A weight at the top counterbalances the gate, extending the aperture of opening and time it remains open. Tide 
Gate 2 (Fig. 3) comprises of a pair of top-hung gates (width $=1.5 \mathrm{~m}$, height $=1.6 \mathrm{~m}$ ), each located at the seaward end of a smooth concrete pipe culvert (diameter $=1.2 \mathrm{~m}$, length $=25.8 \mathrm{~m}$ ). Gates 1 and 2 opened for $7.89 \pm 1.00 \mathrm{~h}$ (mean \pm SD) each tidal cycle at a median angle of $3.5^{\circ}$ (range $=0.7$ $\left.29.8^{\circ}\right)$ and $6.4^{\circ}\left(0.7-22.9^{\circ}\right)$, respectively. When the tide gates are closed, the carrier channel, which terminates $2.7 \mathrm{~km}$ inland from the tide gates, increases the storage capacity and so reduces probability of flooding (Fig. 1). In May 2010, the Environment Agency installed an orifice fish pass half way up Gate 1 (Fig. 2) (width $=0.5 \mathrm{~m}$, height $=0.3 \mathrm{~m}$ ), which comprised of a bottom hinged door that closed at a predetermined tide height under the control of a float. This modification was intended to aid the upstream movement of adult sea trout and juvenile eels past the gates by extending the period of connectivity between the estuary and river whilst maintaining flood protection and minimising saline intrusion upstream by closing at high tide.

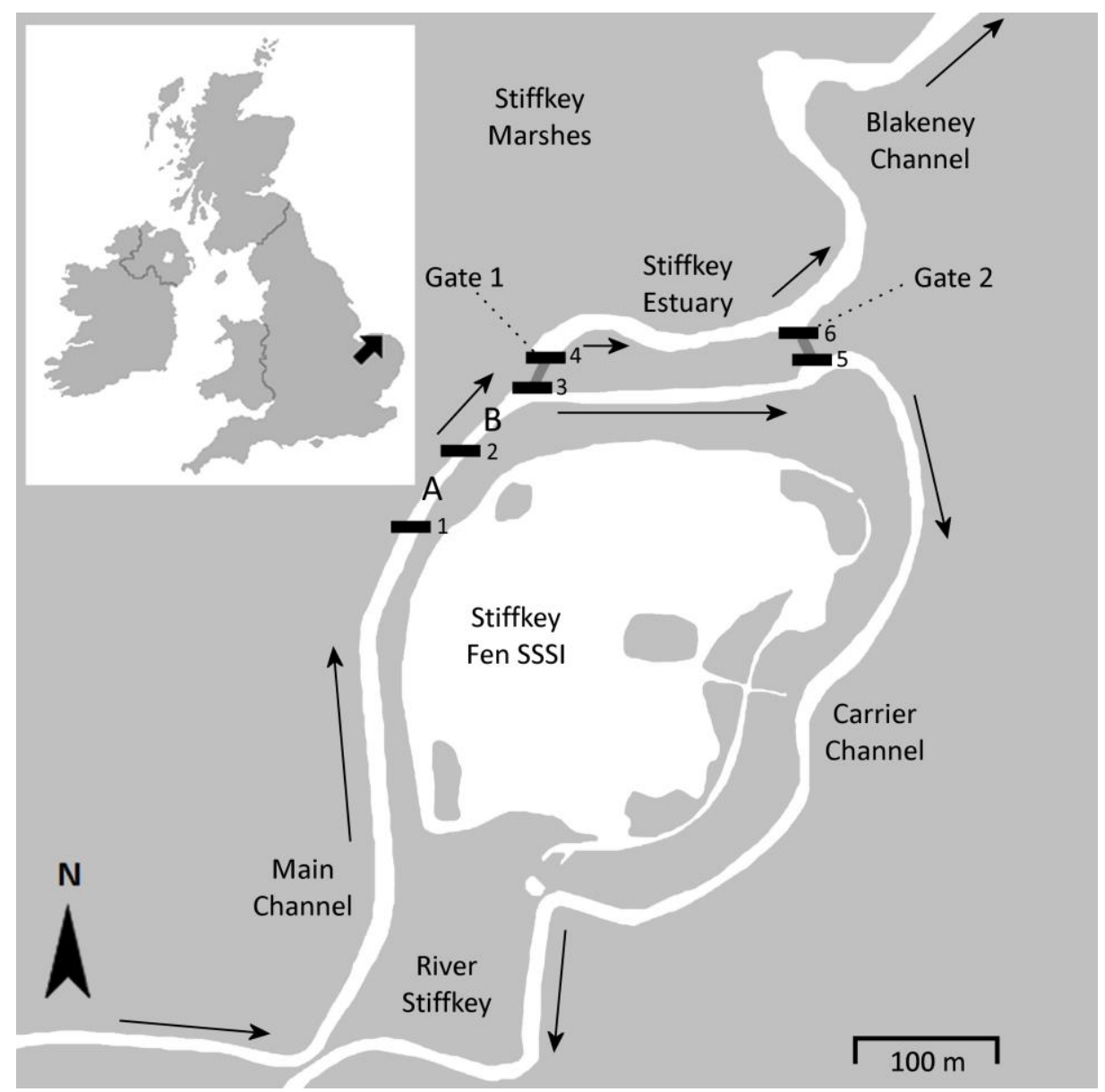

Fig. 1 The lower reaches of the River Stiffkey, North Norfolk (UK), showing direction of water flow $(\rightarrow)$ through Tide Gates 1 and 2. Six PIT loops (PLs, - ) define limits of a control reach (A) containing no structures (between PLs 1 and 2), and a treatment reach (B) containing the tide gates (between PLs 2 and 4 or 6 , dependent on the gate of exit) 


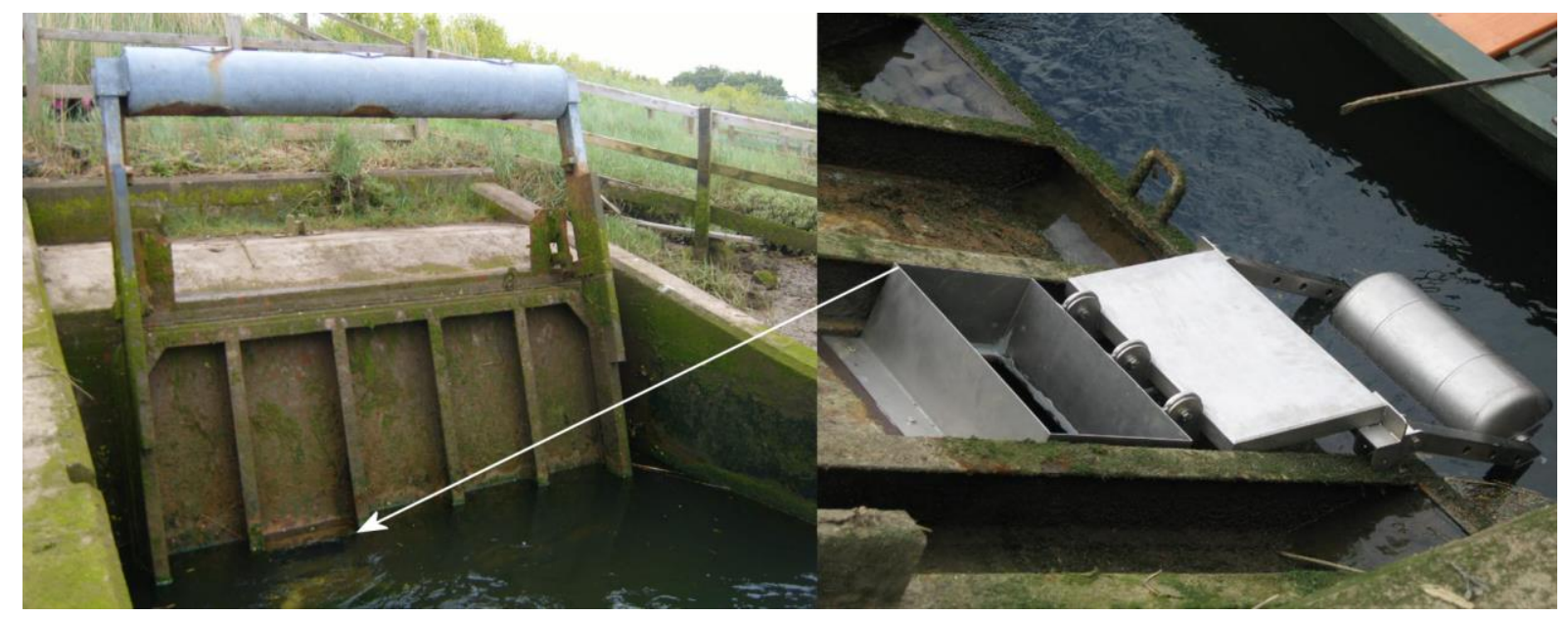

Fig. 2 Left: The counterbalanced top-hung Tide Gate 1 in the River Stiffkey, North Norfolk (UK). Right: An orifice fish pass installed in Gate 1

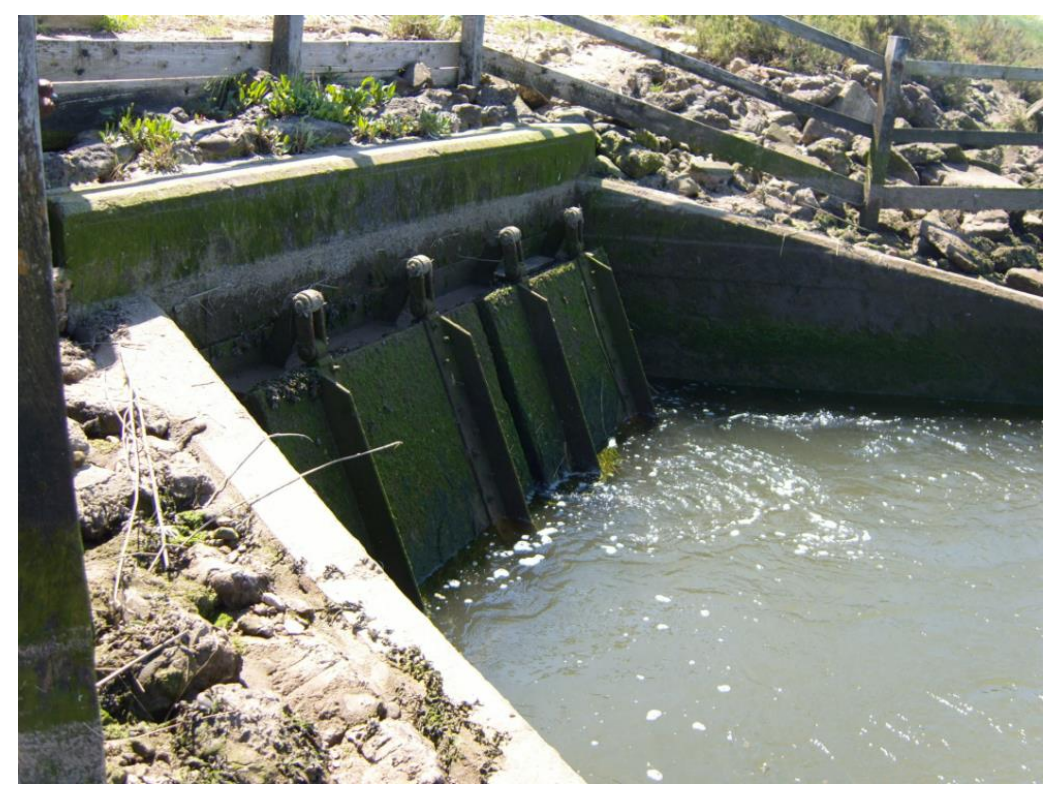

Fig. 3 Tide Gate 2 on the River Stiffkey, North Norfolk (UK), consisting of two top-hung non-counterbalanced gates 


\subsection{Fish capture and telemetry}

The River Stiffkey maintains an established eel population (Pawson 2008). The seaward spawning migration of European eels predominantly occurs during the autumn (Tesch 2003). Therefore, adult eels were caught between July and December 2011 by a combination of electrofishing and trapping (fyke nets) in the River Stiffkey from Buxton Conservation (52 57' 9.76" N; $0^{\circ} 57^{\prime} 20.85^{\prime \prime} \mathrm{E}, 0.5 \mathrm{~km}$ upstream from the tide gates) to Warham $\left(52^{\circ} 56^{\prime} 12.84^{\prime \prime} \mathrm{N} ; 0^{\circ} 54^{\prime} 1.40^{\prime \prime} \mathrm{E}, 6.0 \mathrm{~km}\right.$ upstream from the tide gates). Adult eels were considered migratory if they exhibited the following characteristics when compared to resident yellow eels: (1) white-silver ventral and black dorsal surfaces distinctly separated along the lateral line; (2) large eye diameter to total length (TL) ratio; (3) large pectoral fin length to TL ratio; and (4) darkened pectoral fins (Tesch 2003).

Eels were anaesthetised with MS-222 (300 mg L${ }^{-1}$; buffered to $\mathrm{pH} 7.0$ with $\left.\mathrm{NaHCO}_{3}\right)$, measured and weighed $(n=118, \mathrm{TL}[$ mean $\pm \mathrm{SD}]=384.1 \pm 63.5 \mathrm{~mm}$, mass $[$ mean $\pm \mathrm{SD}]=113.8 \pm 84.4 \mathrm{~g})$, and implanted with a half-duplex passive integrated transponder (PIT) tag (Wyre Micro Design, Lancashire, UK; $2.0 \mathrm{~mm}$ diameter, $23.0 \mathrm{~mm}$ length, $0.61 \mathrm{~g}$ mass) via a ventral incision, in compliance with UK Home Office regulations under the Animals (Scientific Procedures) Act 1986. Mean ( \pm SD) tag length was $6.1 \%( \pm 0.9 \%)$ of $T L$, and mass was $0.6 \%( \pm 0.2 \%)$ of eel mass. Eels recovered from anaesthesia in aerated water for a maximum of 30 minutes prior to release near the site of capture.

A separate sample of eels ( 10 silver eels, $\mathrm{TL}=356.0 \pm 20.1 \mathrm{~mm}$, mass $=79.8 \pm 18.1 \mathrm{~g}$; 10 yellow eels, $\mathrm{TL}=332.9 \pm 18.9 \mathrm{~mm}$, mass $=62.3 \pm 14.9 \mathrm{~g}$ ) were implanted with PIT tags and retained in an instream container receiving natural flow for 7 to 14 days to quantify tag retention and survival. Eels were fed daily with mealworm. Mean $( \pm$ SD) PIT tag length was $6.7 \%( \pm 0.4 \%)$ of TL and mass was $0.7 \%( \pm 0.2 \%)$ of eel mass with $100 \%$ tag retention and survival.

Six half-duplex PIT Loops (PLs) $\left(2.5 \mathrm{~mm}^{2}\right.$ cross sectional area insulated wire consisting of 50 strands of $0.25 \mathrm{~mm}$ diameter copper wire) were constructed on wooden frames (height $=1.8 \mathrm{~m}$, width $=2.5$ - $4.8 \mathrm{~m}$ ) and installed in the lower reaches of the River Stiffkey (Fig. 1). Each PL was connected to a dynamic tuning unit (Wyre Micro Design, Model: DTU), PIT reader (Wyre Micro Design) and external data logger (Anticyclone Systems Ltd, Surrey, UK, Model: AntiLog RS232) and powered by a 110ah $12 v$ battery. PLs 3 - 6 operated continuously from 5 July to 10 December 2011, with the exception of PLs 5 and 6 which operated from 30 September to 6 October and 10 October to 10 December 2011. PLs 1 and 2 operated from 27 October and 19 September 2011 to 10 December 2011, respectively. 
The detection range and efficiency of all PLs were tested at different stages of the tidal cycle throughout the study. Range (maximum distance of detection) was assessed by individually passing three tags oriented parallel and at $45^{\circ}$ to the direction of flow towards the centre, left, and right of the PL and measuring the distance between the PL and the farthest position detection occurred. Range varied from 10 to $50 \mathrm{~cm}$. Efficiency (percentage of tags within range of the PL detected) was quantified by passing three tags, each oriented parallel and at $45^{\circ}$ to the direction of flow, vertically and horizontally, through each PL at $20 \mathrm{~cm}$ intervals to cover its area. PIT tags oriented parallel $\left(90^{\circ}\right.$ to the $\mathrm{PL}$ ) and at $45^{\circ}$ to the direction of flow were passed through PLs at speeds of 0.6 to $2.9 \mathrm{~m} \mathrm{~s}^{-1}$, to replicate the optimal (Palstra et al. 2008) and burst swimming speeds of adult eels (Blaxter and Dickson 1959). Tags tested at lower $\left(0.6-1.6 \mathrm{~m} \mathrm{~s}^{-1}\right)$ and higher speeds $\left(1.6-2.9 \mathrm{~m} \mathrm{~s}^{-1}\right)$ returned similar PL detection efficiencies of $100 \%\left(90^{\circ}\right)$, and $86.5 \%$ and $85.7 \%\left(45^{\circ}\right)$, respectively (Table 1 ). Efficiency for $90^{\circ}$ oriented tags was $98-100 \%$ when the tide gates were open. Efficiency for $45^{\circ}$ oriented tags was $100 \%$ for the majority of the time the gates were open, decreasing to $71-93 \%$ immediately after the gates opened before rapidly returning to $100 \%$.

Table 1 Detection range and efficiency for 6 PIT loops (PLs) in the lower River Stiffkey (UK) tested with tags oriented at $90^{\circ}$ and $45^{\circ}$ to each PL across their area and at speeds $1\left(0.6-1.6 \mathrm{~m} \mathrm{~s}^{-1}\right)$ and $2\left(1.6-2.9 \mathrm{~m} \mathrm{~s}^{-1}\right)$. Ranges are reported in parentheses

\begin{tabular}{|c|c|c|c|c|c|c|}
\hline \multirow[t]{2}{*}{ PL Number } & \multirow[t]{2}{*}{ Tag Orientation $\left({ }^{\circ}\right)$} & \multirow[t]{2}{*}{ Range $(\mathrm{cm})$} & \multicolumn{4}{|c|}{ Detection Efficiency } \\
\hline & & & Area & & Speed 1 & Speed 2 \\
\hline \multirow[t]{2}{*}{1} & 90 & 50 & 98 & $(93-100)$ & 100 & 100 \\
\hline & 45 & 45 & 100 & & 100 & 100 \\
\hline \multirow[t]{2}{*}{2} & 90 & 50 & 100 & & 100 & 100 \\
\hline & 45 & 45 & 100 & & 100 & 100 \\
\hline \multirow[t]{2}{*}{3} & 90 & 35 & 100 & & 100 & 100 \\
\hline & 45 & 30 & 86 & $(71-100)$ & 83 & 73 \\
\hline \multirow[t]{2}{*}{4} & 90 & 35 & 100 & & 100 & 100 \\
\hline & 45 & 10 & 90 & $(76-100)$ & 78 & 85 \\
\hline \multirow[t]{2}{*}{5} & 90 & 40 & 100 & & 100 & 100 \\
\hline & 45 & 40 & 100 & & 100 & 100 \\
\hline \multirow[t]{2}{*}{6} & 90 & 45 & 100 & & 100 & 100 \\
\hline & 45 & 45 & 100 & & 100 & 100 \\
\hline
\end{tabular}




\subsection{Environmental variables}

Water temperature, conductivity, water pressure and barometric pressure (Solinst, Georgetown, Ontario, Canada; Model LTC Levelogger Junior 3001 and Barologger Gold 3001) were logged at 5 minute intervals immediately upstream and downstream of Gate 1 from September to December 2011. From these measurements, water depth and salinity were calculated (Fofonoff and Millard 1983). Opening angles of Gates 1 and 2 were logged at 2 minute intervals over the same period via tri-axial static acceleration loggers (Onset, Bourne, Massachusetts, USA; Model UA-004-64), and calibrated weekly using a tape measure. Light intensity (Onset, Bourne, Massachusetts, USA; Model UA-002-64) and river discharge were recorded at 15 minute intervals at the tide gates and the Environment Agency gauging station at Little Walsingham (12.6 km upstream from the tide gates), respectively. Light intensity was 0 lux at night (between the hours of sunset and sunrise) and $>0$ lux during the day.

\subsection{Video data}

To assess the influence of the orifice installed in Gate 1 on the downstream migration of adult eels, the orifice was set to either 'operational', or 'non-operational' on alternate days throughout the study period. When operational, the orifice functioned as intended, remaining open at low water, and closing on average $( \pm S D) 14.8( \pm 8.0)$ min after the closure of Gate 1 during the flood tide. When non-operational, the orifice door was manually clamped shut for the entire duration of each tidal cycle.

During periods of operation, the orifice was monitored by two infrared (IR) submersible cameras with integrated IR LEDs (Sony, Model: IR 37CSHR-IR 25m). The cameras were mounted at either side of the orifice, perpendicular to the flow, to (1) observe the entire entry area, and (2) emit an IR light source from behind any fish using the orifice so that passage could also be viewed at night. The cameras operated throughout the study period, with the exception of the night of 25 November 2011, during which 1 tagged eel passed Gate 1. Video footage was recorded to a digital video recorder powered by a 110ah $12 \mathrm{v}$ battery and downloaded at weekly intervals. Footage recorded between the time of last eel detection at PL3 and first detection at PL4 was then manually reviewed to identify any orifice passage events. 


\subsection{Data analyses}

\subsubsection{Escapement}

Eel escapement was assessed between 10 October and 10 December 2011 when PLs 2 to 6 were operational. Escapement was calculated as the number of fish detected at PLs 4 and 6 (downstream of the gates) as a percentage of those detected at PL 2 (upstream of the gates).

\subsubsection{Delay}

The study site was divided into two reaches for analysis: (1) control reach A in which water control structures were absent (length $=55 \mathrm{~m}$ ), and (2) treatment reach B which included the carrier channel and the tide gates (for fish exiting via Gate 1: length of reach = $85 \mathrm{~m}$; Gate 2: length $=290 \mathrm{~m}$ ) (Fig. 1). The speed of migration was calculated for each reach as the quotient of the distance $(\mathrm{m})$ separating upstream and downstream PLs and duration (s) between first detection at each. Data from 27 October 2011 onwards were square root transformed to comply with the assumption of normality (Kolmogorov-Smirnov test: $P>0.05$ ). Eels were categorised based on their exit route as those that either initially passed Gate 1 or 2. A one-way repeated-measures ANOVA was used to compare speed of migration between reaches for the two groups. Independent $t$-tests were used to compare speed of migration through each reach between exit routes (Gate 1 or Gate 2).

Mean discharge $\left(Q_{\text {fish }}\right)$, water temperature $\left(T e m p_{\text {fish }}\right)$, gate angle (Angle $\left.{ }_{\text {fish }}\right)$ and light intensity (Light $_{\text {fish}}$ ) during passage through reaches A and B were calculated for individual fish. Although confounding data could not be transformed to comply with the assumption of normality (Kolmogorov-Smirnov test: $P<0.05$ ), repeated-measures ANOVAs, which are robust to such deviations when sample sizes are equal (Harwell et al., 1992), were used to compare $Q_{\text {fish, }}$ Temp $_{\text {fish, }}$ Angle $_{\text {fish }}$ and Light ${ }_{\text {fish }}$ between reaches within exit route groups to identify any temporal differences in these variables experienced by eels. Where data were normally distributed, or parametric analysis was used, data were reported as means $( \pm S D)$.

Multiple linear regression models were developed to explore the overall relationships between speed of migration and environmental variables $\left(\mathrm{Q}_{\mathrm{fish}}, \mathrm{Temp}_{\mathrm{fish}}, \mathrm{Angl}_{\mathrm{fish}}\right.$ and Light $\left._{\mathrm{fish}}\right)$ in reaches $\mathrm{A}$ and B ( $n=32$ ) from 27 October to 10 December 2011 when all 6 PLs were functional. A KolmogorovSmirnov test indicated that standardised residuals were normally distributed $(P>0.05)$. To increase 
statistical power, an additional multiple linear regression model was used to explore the relationship between these variables for fish migrating through reach B between 10 October and December 2011 ( $n=58$ ) when PLs 2 to 6 were functional. Raw data were square root transformed to provide normally distributed standardised residuals (Kolmogorov-Smirnov test, $P>0.05$ ). Date/time and TL had no independent relationship with speed and were thus omitted from further analysis. Regression analyses were reported as unstandardised $B$ coefficients and $95 \%$ confidence intervals $(C l)$ with variance $\left(R^{2}\right)$ indicated as percentages.

As data could not be transformed to meet the assumption of normality (Kolmogorov-Smirnov test: $P$ $<0.05)$, Mann-Whitney $(U)$ tests were used to assess the relationship (including effect size, $r$ ) between exit route (Gate 1 or Gate 2), gate position (open or closed), time of day (day or night), or status of orifice operation (operational or non-operational) when fish entered treatment reach $B$ on the speed of migration through that reach $(n=58)$. Chi-square $\left(X^{2}\right)$ was used to explore the relationship between gate position when eels entered reach B (open or closed) and route of exit (Gate 1 or Gate 2) and status of orifice operation (operational or non-operational). Spearman's rho $\left(r_{s}\right)$ was used to assess the relationship between (1) speed of migration between release and PL2 with distance and release date, and (2) gate angle at passage (detection at PLs 4 or 6) and duration of migration through the respective culvert (time between detection at PLs 3 or 5 and 4 or 6 ).

Mann-Whitney tests were used to compare the association between status of orifice operation (operational or non-operational) when fish entered reach B and $Q_{\text {fish, }}$ Temp $_{\text {fish }}, A_{\text {ngle }}$ fish $_{\text {, }}$ Light $_{\text {fish }}$ and

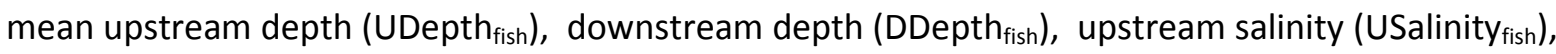
and downstream salinity (DSalinity ${ }_{\text {fish }}$ ) calculated for individual fish. Where data were not normally distributed and non-parametric analyses were used, results were reported as medians with ranges in parentheses.

The number of approaches immediately upstream of the gates and culverts (detection at PLs 3 and 5) was calculated. Each approach was defined as detection at PL3 or PL5 with an interval of $>5$ min apart. A Wilcoxon signed-rank $(T)$ test was used to compare downstream and upstream migration duration through the culverts for fish that re-entered the river. 


\subsubsection{Environmental data}

\subsubsection{Tide gates}

Water temperature and salinity measurements collected over the entire duration of the study period were compared using Mann-Whitney tests to explore their relationship with tide gate position (open or closed).

\subsubsection{Orifice status}

When the gates were closed, Mann-Whitney tests were used to compare water temperature, salinity and difference in depth ( $\Delta$ Depth) between upstream and downstream for each orifice status (operational or non-operational), as well as to compare gate angle and upstream depth between each orifice status when the gates were open.

\section{Results}

\subsection{Escapement}

Of the 118 PIT tagged eels released, 67.8\% $(n=80)$ were detected at PL 2, $65 \mathrm{~m}$ upstream of Gate 1. Of these, 59 eels reached PL 2 between 10 October and 10 December 2011 when PLs 2 to 6 were operational, 58 of which were detected at PLs 4 and 6 downstream of the tide gates by December 2011 , giving a total escapement of $98.3 \%$ for those that approached the tide gates. More eels exited the river for the first time via Gate $1(75.9 \%, n=44)$ than Gate $2(24.1 \%, n=14)$. Nine eels reentered the river once via Gate $1(15.5 \%)$, predominately during the ebb tide, on average $( \pm$ SD) 1.92 $( \pm 1.39) \mathrm{h}$ after the gates opened. No eels re-entered through Gate 2 . Almost half of those that reentered finally exited through Gate $2(n=4)$ rather than Gate $1(n=5)$, with a total of $69.0 \%$ of eels ( $n=40$ ) finally exiting via Gate 1 and $31.0 \%(n=18)$ via Gate 2 . Eels were less likely to re-enter the river if they exited for the first time through Gate $2(n=1)$ but there was no difference in TL $(U=$ $159.00, r=-0.16, P>0.05)$ between those that re-entered and those that did not. All eels that reentered the river remained downstream of PL2. 


\subsection{Delay}

The median duration and speed of migration of eels from the release locations $(0.5$ to $3.1 \mathrm{~km}$ upstream from the tide gates) to PL2 was $1.3(0.1-69.3)$ days and $0.004(0.0001-0.06) \mathrm{m} \mathrm{s}^{-1}$, respectively. Speed of migration between these two points was related to distance of the release site from PL2 $\left(r_{s}=-0.37, P<0.01\right)$ and release date $\left(r_{s}=0.69, P<0.001\right)$.

For the 32 eels detected while PL1 was functional, speed of migration was faster through the control (A) than the treatment (B) reach regardless of exit route (Fig. 4; Table 2). Speed of migration through reach A did not differ between eels that departed through Gate 1 or $2\left(t_{30}=-0.12, P>0.05\right)$, although those that escaped through Gate 1 did migrate more rapidly through reach $B\left(t_{29.4}=2.34, P\right.$ $<0.05$ ). When including eels $(n=58)$ that migrated earlier in the season (when PL1 was out of operation), median speed of migration (Gate 1: 0.04 [0.0001 - 0.37] $\mathrm{m} \mathrm{s}^{-1}$; Gate 2: 0.03 [0.0002 - 0.07] $\left.\mathrm{m} \mathrm{s}^{-1}\right)$ through reach $B$ was not dependant on exit route $(U=265.00, r=-0.10, P>0.05)$. Median duration of passage through reach B was 0.67 [0.06 - 406.61] h and 3.13 [1.24 - 360.32] h for eels ( $n$ $=58)$ that exited via Gates 1 and 2, respectively.

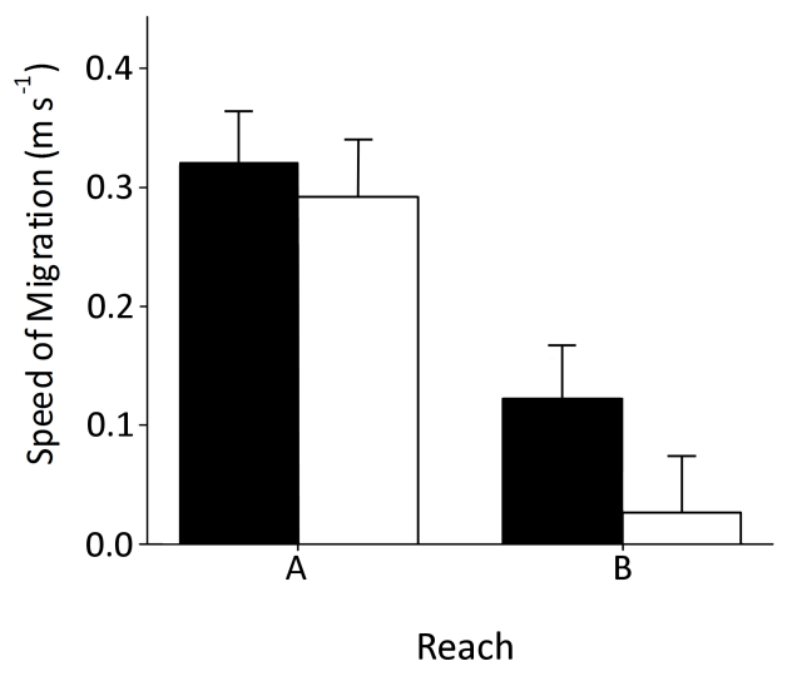

Fig. 4 Mean \pm SE speed of migration of 32 adult European eels through a control reach with no structure (A) and a treatment reach with tide gates (B) in the lower River Stiffkey (UK) between October and December 2011. Eels exited the system via Tide Gate 1 ( $\square$ ) or Tide Gate 2 ( $\square$ ) 
Table 2 Mean \pm SD duration, speed of migration, Temp $_{\text {fish }}, \mathrm{Q}_{\text {fish }}$, Light $_{\text {fish }}$, and Angle $\mathrm{fish}_{\text {for }} 32$ PIT tagged adult European eels migrating downstream in the River Stiffkey (UK) through a control reach with no structures (A) and a treatment reach (B) where eels can exit the system via Tide Gate 1 or Tide Gate 2, with results of repeated-measures ANOVAs comparing reaches $A$ and $B$

\begin{tabular}{|c|c|c|c|c|c|c|c|c|c|}
\hline & \multirow{2}{*}{ Exit Route } & \multicolumn{4}{|c|}{ Reach } & \multicolumn{4}{|c|}{ Repeated Measures ANOVA } \\
\hline & & $A$ & & $\mathrm{~B}$ & & $F$ & $d f$ & error & $P$ \\
\hline \multirow[t]{2}{*}{ Duration (h) } & Gate 1 & $1.11 \pm$ & 4.65 & $66.24 \pm$ & 141.76 & & & & \\
\hline & Gate 2 & $0.07 \pm$ & 0.05 & $53.34 \pm$ & 125.16 & & & & \\
\hline \multirow[t]{2}{*}{ Speed $\left(\mathrm{m} \mathrm{s}^{-1}\right)$} & Gate 1 & $0.32 \pm$ & 0.23 & $0.12 \pm$ & 0.13 & 21.67 & 1 & 23 & $0.000^{* *}$ \\
\hline & Gate 2 & $0.29 \pm$ & 0.13 & $0.03 \pm$ & 0.02 & 43.84 & 1 & 7 & $0.000^{* *}$ \\
\hline \multirow[t]{2}{*}{$\operatorname{Temp}_{\text {fish }}\left({ }^{\circ} \mathrm{C}\right)$} & Gate 1 & $10.43 \pm$ & 2.05 & $10.06 \pm$ & 1.99 & 6.95 & 1 & 23 & $0.015^{*}$ \\
\hline & Gate 2 & $10.81 \pm$ & 1.78 & $10.53 \pm$ & 1.75 & 0.78 & 1 & 7 & 0.406 \\
\hline \multirow[t]{2}{*}{$Q_{\text {fish }}\left(m^{3} s^{-1}\right)$} & Gate 1 & $0.11 \pm$ & 0.03 & $0.10 \pm$ & 0.03 & 4.32 & 1 & 23 & $0.049^{*}$ \\
\hline & Gate 2 & $0.12 \pm$ & 0.06 & $0.12 \pm$ & 0.05 & 2.65 & 1 & 7 & 1.148 \\
\hline \multirow[t]{2}{*}{ Light $_{\text {fish }}$ (lux) } & Gate 1 & $72.23 \pm$ & 353.83 & $291.87 \pm$ & 499.24 & 2.77 & 1 & 23 & 0.110 \\
\hline & Gate 2 & $0.00 \pm$ & 0.00 & $253.18 \pm$ & 473.08 & 2.29 & 1 & 7 & 0.174 \\
\hline \multirow[t]{2}{*}{ Angle $_{\text {fish }}\left({ }^{\circ}\right)$} & Gate 1 & $8.07 \pm$ & 9.02 & $9.64 \pm$ & 7.90 & 4.98 & 1 & 23 & $0.036^{*}$ \\
\hline & Gate 2 & $1.29 \pm$ & 2.80 & $5.04 \pm$ & 2.64 & 5.41 & 1 & 7 & 0.053 \\
\hline
\end{tabular}

${ }^{*} P<0.05$

${ }^{* *} P<0.001$

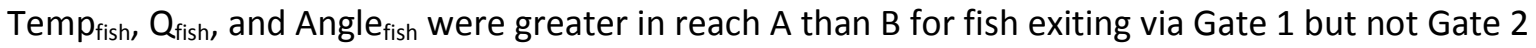

(Table 2). There was no variation in Light $_{\text {fish }}$ between reaches $A$ and $B$ for either route of exit.

Overall, $\mathrm{Q}_{\text {fish }}$, Temp $_{\text {fish }}$, Light fish $_{\text {and Angle }}$ fish explained $24.1 \%$ and $57.0 \%$ of the variation in speed of migration through reaches $A$ and $B$, respectively. The regression for reach $A$ returned no significant correlates. Angle fish $(B=0.007, C l=0.002-0.012, P<0.01)$ had the most significant relationship with speed of migration through reach $B$ followed by Light $_{\text {fish }}(B=0.000, C l=0.000-0.000, P<0.01)$. In the regression model for 58 eels, $\mathrm{Q}_{\text {fish, }}$ Temp fish $_{\text {, }}$ ight $_{\text {fish }}$ and Angle $\mathrm{e}_{\text {fish }}$ accounted for $60.5 \%$ of the variability in speed of migration, with Light $_{\text {fish }}$ being the most significant correlate $(B=-0.007, C l=-$ $0.010--0.005, P<0.001)$ followed by Angle $\mathrm{fish}_{(}(B=0.065, C l=0.030-0.100, P<0.001)$ and Temp $\mathrm{p}_{\mathrm{fish}}$ $(B=-0.155, C l=-0.292--0.019, P<0.05)$.

Median speed of migration through reach B was faster if the gates were open when eels entered the reach $\left(n=28,0.12[0.0001-0.37] \mathrm{m} \mathrm{s}^{-1}\right)$ than when closed $\left(n=30,0.01[0.0001-0.23] \mathrm{m} \mathrm{s}^{-1}\right)(U=$ 227.50, $r=-0.39, P<0.01$ ). If Gate 1 was open when entering reach B (detection at PL 2 ), eels were 
more likely to exit through this route $\left(89.3 \%\right.$ versus $63.3 \%$ when closed, $\left.X^{2}{ }_{1}=5.33, P<0.05\right)$. All fish entered both reaches, and passed through the gates (detection at PLs 4 and 6), at night (0 lux). Eels passed the gates predominately during the onset of the ebb tide, a median of $39.7(0.3-449.8) \mathrm{min}$ after the gates opened. Duration of migration through the culverts (median $=74 \mathrm{~s}$, range $=24-1381$ s) was negatively related to gate angle at passage (median $=16.8^{\circ}$, range $\left.=2.1-27.8^{\circ}\right)\left(r_{s}=-0.36, P<\right.$ $0.01)$.

Eels migrated faster through reach $B$ when the orifice was operational $(n=28,0.07$ [0.0001 - 0.37] $\mathrm{m}$ $\left.\mathrm{s}^{-1}\right)$ compared to non-operational $\left(n=30,0.01[0.0001-0.33] \mathrm{m} \mathrm{s}^{-1}\right)(U=231.00, r=-0.39, P<0.01)$

(Fig. 5). However, video analysis revealed that eels did not pass through the orifice. Status of orifice

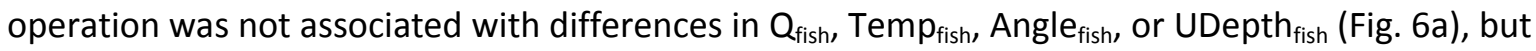
was related to lower USalinity $y_{\text {fish }}$ (Fig. 6b), which was likely a result of lower DDepth fish $_{\text {(i.e. lower }}$ tides) (Fig. 6c), and DSalinity fish (Fig. 6d) when the orifice was operational. Light fish $_{\text {was also lower }}$ when the orifice was open at entry to reach B (Table 3 ) and the number of cases where Gate 1 was open when eels entered reach $B$ was higher $\left(X^{2}{ }_{1}=5.56, P<0.05\right)$.

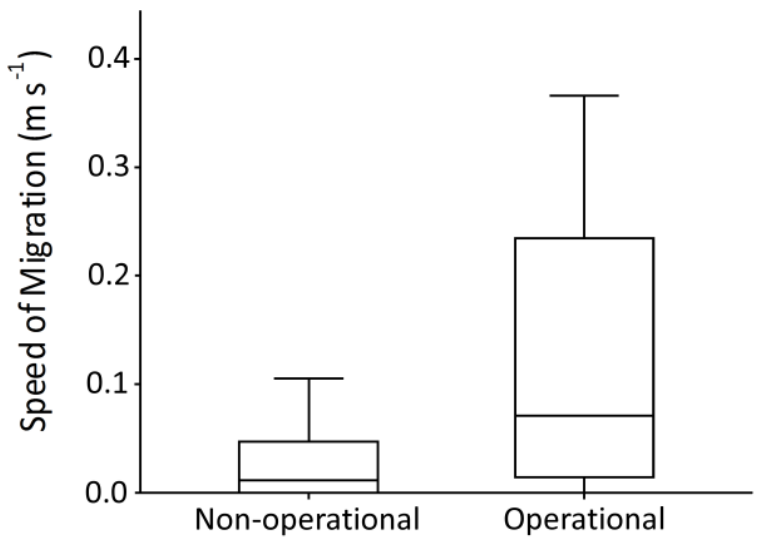

Orifice Status

Fig. 5 Speed of migration of 58 adult European eels through the lower River Stiffkey (UK) when an orifice in Tide Gate 1 was non-operational or operational. The box plots illustrate the median (horizontal line), interquartile range (boxes) and overall range up to 1.5 times the interquartile range (whiskers). Outliers $>1.5$ times the interquartile range are not depicted 


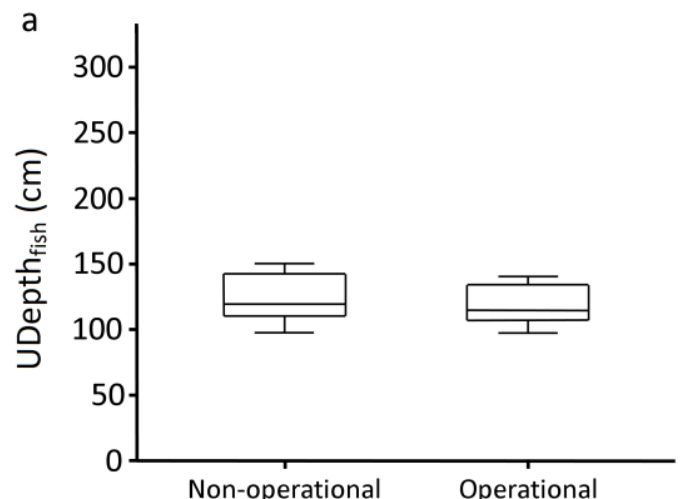

Orifice Status

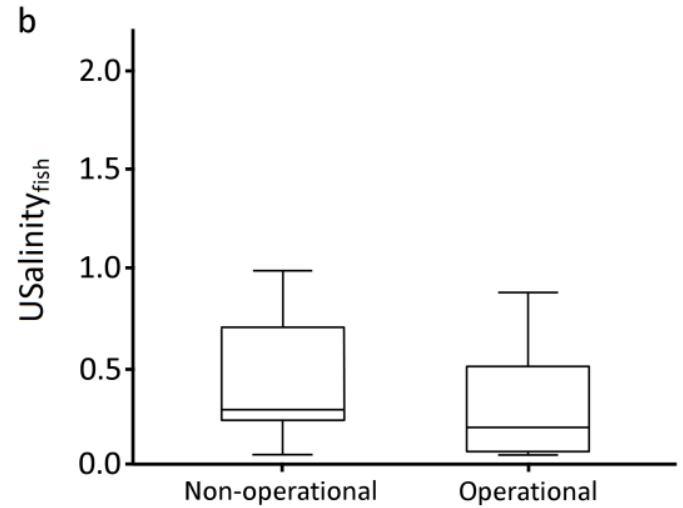

Orifice Status

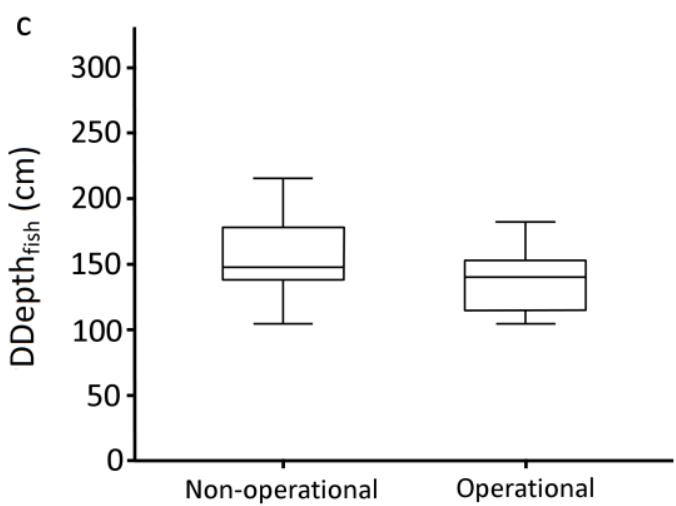

Orifice Status

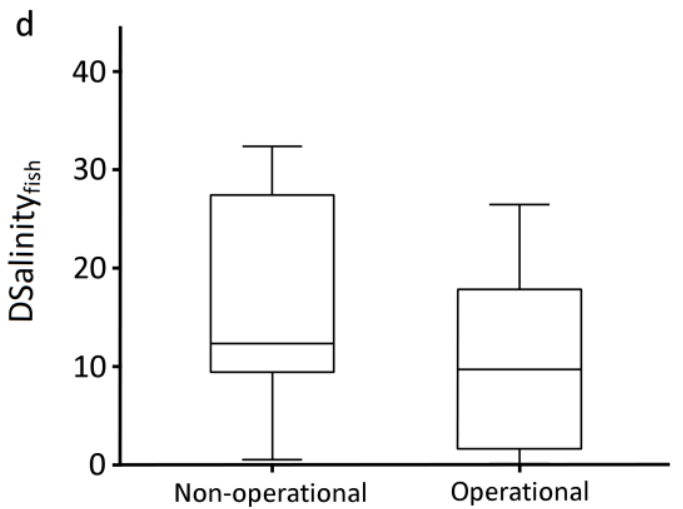

Orifice Status

Fig. 6 (a) UDepth fish, $_{\text {(b) USalinity }}$ fish, (c) DDepth fish, $_{\text {, and (d) DSalinity }}$ fish $_{\text {for }} 58$ adult European eels through the lower River Stiffkey (UK) when an orifice in Tide Gate 1 was non-operational or operational. The box plots illustrate the median (horizontal line), interquartile range (boxes) and overall range up to 1.5 times the interquartile range (whiskers). Outliers $>1.5$ times the interquartile range are not depicted

Table 3 Mann-Whitney statistical comparisons of $Q_{\text {fish }}$, Temp fish $_{\text {, Angle }}$ fish, UDepth fish $_{\text {, Depth }}$ fish, USalinity $_{\text {fish, }}$

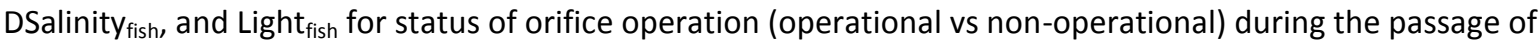
58 adult European eels through reach $B$ containing tide gates

\begin{tabular}{lccc}
\hline & \multicolumn{3}{c}{ Mann-Whitney } \\
\cline { 2 - 4 } & $U$ & $r$ & $P$ \\
\hline $\mathrm{Q}_{\text {fish }}$ & 350.00 & -0.14 & 0.276 \\
Temp $_{\text {fish }}$ & 338.00 & -0.17 & 0.202 \\
Angle $_{\text {fish }}$ & 384.00 & -0.07 & 0.575 \\
UDepth $_{\text {fish }}$ & 275.00 & -0.17 & 0.209 \\
DDepth $_{\text {fish }}$ & 218.00 & -0.31 & $0.023^{*}$ \\
USalinity $_{\text {fish }}$ & 231.00 & -0.28 & $0.041^{*}$ \\
DSalinity $_{\text {fish }}$ & 238.00 & -0.29 & $0.034^{*}$ \\
Light $_{\text {fish }}$ & 302.00 & -0.30 & $0.022^{*}$ \\
\hline$P<0.05$ & & &
\end{tabular}


Fifteen eels (25.9\%) explored the area upstream of one gate (detection at PL 3 or 5 ) before passing through the other (detection at PL 6 or 4, respectively). Twenty-two eels (37.9\%) made more than one approach to the culverts (detection at PL3 or PL5, mean \pm SD number of approaches $=4.0 \pm 2.9$ ) and the majority $(89.7 \%, n=52)$ remained in the area downstream from PL2 after entering reach $\mathrm{B}$ and prior to passage. Of the eels migrating $(n=58), 74.1 \%$ passed through reach $B$ during the same period as one or more other tagged individuals, with a maximum of 7 being present at any one time. Eels that re-entered the river after first passage through the gates $(15.5 \%, n=9)$ took a median of $2.0(1.0-22.1)$ days to pass downstream of the tide gates for the final time. There was no variation in the duration of passage through the culvert between movement downstream or upstream $(T=17$, $r=-0.15, P>0.05)$.

\subsection{Environmental data}

\subsubsection{Tide gates}

Assessment of the relationship between the tide gates and environmental variables alone showed that upstream and downstream median temperatures (Table 4) were marginally higher when the gates were closed than when open over the full duration of the study (Table 5; Fig. 7a). The median temperature upstream and downstream of the gates was different when closed, but similar when open (Table 5). 
Table 4 Median water temperature, salinity and depth upstream and downstream of Tide Gate 1 when open and closed, or during periods of gate closure when the orifice was operational and non-operational, from 23 September to 30 November 2011, with ranges in parentheses

\begin{tabular}{|c|c|c|c|c|c|}
\hline & Location & Status & Temperature $\left({ }^{\circ} \mathrm{C}\right)$ & Salinity & Depth (cm) \\
\hline \multirow[t]{4}{*}{ Gate } & \multirow[t]{2}{*}{ Upstream } & Open & $10.76(6.28$ - 16.95) & $0.54(0.37-13.80)$ & 98.10 (94.78 - 158.36) \\
\hline & & Closed & $11.12(6.48-17.14)$ & $7.92(0.33-13.38)$ & $128.80(96.03-159.63)$ \\
\hline & \multirow[t]{2}{*}{ Downstream } & Open & $10.77(5.96-17.15)$ & $0.90(0.37-32.64)$ & $100.12(95.80-163.33)$ \\
\hline & & Closed & $11.60(5.92-18.76)$ & $28.84(0.41-34.70)$ & 211.95 (98.94 - 444.86) \\
\hline \multirow{4}{*}{$\begin{array}{l}\text { Orifice } \\
\text { (Gate Open) }\end{array}$} & \multirow[t]{2}{*}{ Upstream } & Operational & $11.21(6.88-16.95)$ & $0.53(0.37-13.50)$ & 97.95 (94.85 - 158.07) \\
\hline & & Non-operational & $10.61(6.28-16.95)$ & $0.54(0.37-13.80)$ & 98.21 (94.78 - 158.36) \\
\hline & \multirow[t]{2}{*}{ Downstream } & Operational & $11.21(6.88-16.96)$ & $0.86(0.40-31.84)$ & $100.11(95.88-161.91)$ \\
\hline & & Non-operational & $10.62(5.96-17.15)$ & $0.95(0.37-32.64)$ & 100.19 (95.80 - 163.33) \\
\hline \multirow{4}{*}{$\begin{array}{l}\text { Orifice } \\
\text { (Gate Closed) }\end{array}$} & \multirow[t]{2}{*}{ Upstream } & Operational & 11.45 (7.02 - 17.08) & $7.89(0.37-12.92)$ & 129.29 (96.58 - 158.07) \\
\hline & & Non-operational & $11.02(6.48$ - 17.14) & $7.94(0.33-13.38)$ & $128.51(96.42-159.63)$ \\
\hline & \multirow[t]{2}{*}{ Downstream } & Operational & 11.74 (6.99 - 18.63) & $28.54(0.41-34.70)$ & 211.15 (99.58 - 372.48) \\
\hline & & Non-operational & $11.48(5.92$ - 18.76) & $29.02(0.45-33.83)$ & $212.41(100.41-444.86)$ \\
\hline
\end{tabular}


Table 5 Mann-Whitney statistical comparisons of water temperature, salinity and depth over the entire period of eel movement during the study (23 September to 30 November 2011) upstream (US) and downstream (DS) of Tide Gate 1 when open and closed, or during periods of gate closure when the orifice was operational and nonoperational

\begin{tabular}{|c|c|c|c|c|c|c|c|c|c|c|c|}
\hline & \multirow{2}{*}{ Comparison } & \multirow{2}{*}{$\begin{array}{l}\text { Status or } \\
\text { Location }\end{array}$} & \multicolumn{3}{|c|}{ Temperature } & \multicolumn{3}{|c|}{ Salinity } & \multicolumn{3}{|c|}{ Depth } \\
\hline & & & $U$ & $r$ & $P$ & $U$ & $r$ & $P$ & $U$ & $r$ & $P$ \\
\hline \multirow[t]{4}{*}{ Gate } & \multirow{2}{*}{ US vs DS } & Open & 70796947.00 & 0.00 & 0.627 & 35194139.50 & -0.44 & $0.000^{* *}$ & 42474802.00 & -0.35 & $0.000^{* *}$ \\
\hline & & Closed & 20892517.50 & -0.10 & $0.000^{* *}$ & 5992891.50 & -0.65 & $0.000^{* *}$ & 2537395.50 & -0.78 & $0.000^{* *}$ \\
\hline & \multirow{2}{*}{ Open vs Closed } & US & 954959441.50 & -0.06 & $0.000^{* *}$ & 416226210.00 & -0.50 & $0.000^{* *}$ & 144048659.50 & -0.72 & $0.000^{* * *}$ \\
\hline & & DS & 845468032.50 & -0.15 & $0.000^{* *}$ & 207504262.50 & -0.67 & $0.000^{* *}$ & 16694109.00 & -0.82 & $0.000^{* *}$ \\
\hline \multirow[t]{4}{*}{ Orifice } & \multirow{4}{*}{$\begin{array}{l}\text { Operational vs } \\
\text { Non-operational }\end{array}$} & Open (US) & 360502753.00 & -0.09 & $0.000^{* *}$ & 382073083.50 & -0.05 & $0.000^{* *}$ & 376628644.50 & -0.05 & $0.000^{* *}$ \\
\hline & & Open (DS) & 361374699.00 & -0.09 & $0.000^{* *}$ & 391558228.50 & -0.03 & $0.000^{* *}$ & 373744887.50 & -0.06 & $0.000^{* *}$ \\
\hline & & Closed (US) & 126194307.00 & -0.04 & $0.000^{* *}$ & 132395311.50 & 0.00 & 0.600 & 5274885.50 & -0.03 & $0.004^{*}$ \\
\hline & & Closed (DS) & 128059556.50 & -0.03 & $0.000^{* *}$ & 126837062.50 & -0.04 & $0.000^{* *}$ & 5501755.50 & 0.00 & 0.930 \\
\hline
\end{tabular}

$$
{ }^{* *} P<0.001
$$



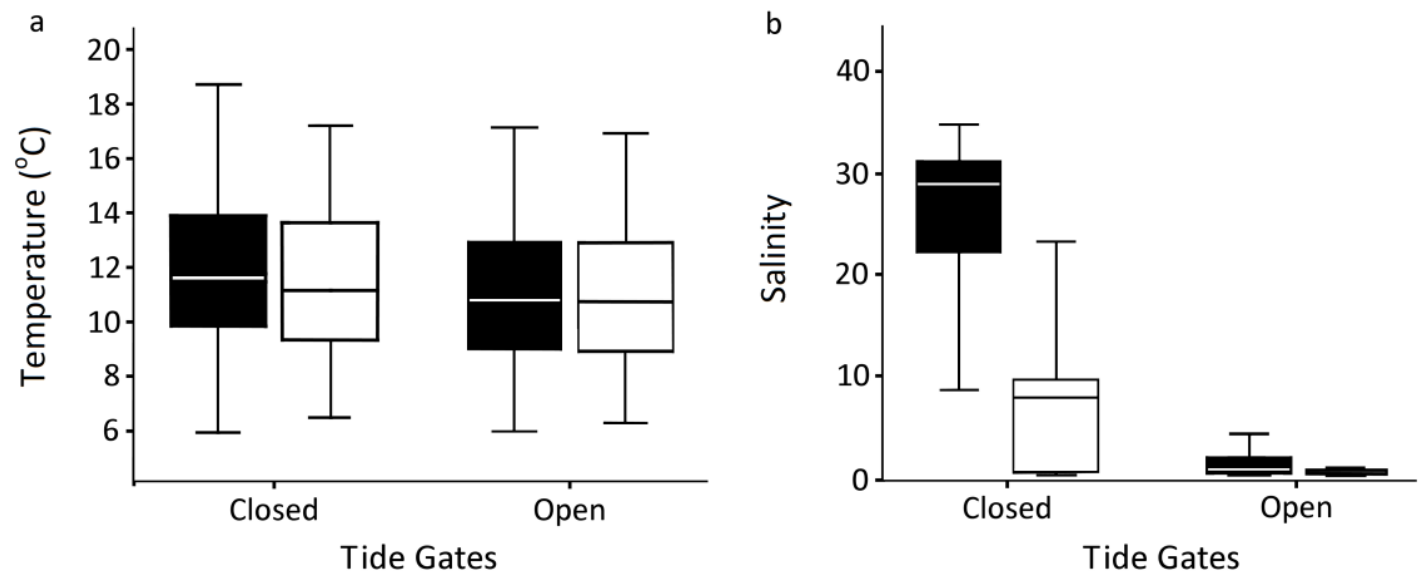

Fig. 7 (a) Water temperature and (b) salinity downstream ( $\square$ ) and upstream ( $\square$ ) of Tide Gate 1 in the River Stiffkey (UK) when the gate was open and closed from 23 September to 30 November 2011 . Outliers $>1.5$ times the interquartile range are not depicted

Upstream and downstream median salinity (Table 4) was substantially higher when the gates were closed than when open for the duration of the study (Table 5; Fig. 7b). Median salinity was slightly different between upstream and downstream when the gates were open, but considerably higher downstream when closed (Table 5).

\subsubsection{Orifice status}

Status of orifice operation (operational or non-operational) did not influence upstream median salinity over the period of study when the gates were closed (Table 4; Table 5) and was not associated with variation in median $\Delta$ Depth (Table 6) even though downstream median salinity was higher when the orifice was non-operational. Median upstream water temperature also varied with status of orifice operation which likely resulted from differences in downstream temperature (Table 4; Table 5). When the gates were open, the median angle of Gate 1 (Table 6) and upstream depth (Table 4; Table 5) were marginally higher when the orifice was non-operational. 
Table 6 Mann-Whitney statistical comparisons of opening angle of Tide Gate 1 and difference in water depth between upstream and downstream ( $\Delta$ Depth) when the gate was closed, measured over the entire period of eel movement during the study (23 September to 30 November 2011)

\begin{tabular}{llrccc}
\hline & \multicolumn{1}{c}{ Status } & Median (Range) & $U$ & $r$ & $P$ \\
\hline \multirow{2}{*}{ Gate Angle $\left(^{\circ}\right)$} & Operational & $3.50(0.65-29.50)$ & 279652651.00 & -0.26 & $0.000^{*}$ \\
& Non-operational & $3.51(0.65-29.50)$ & & & \\
\hline \multirow{2}{*}{ Depth $(\mathrm{cm})$} & Operational & $81.96(-1.09-244.56)$ & 135721224.50 & -0.01 & 0.053 \\
& Non-operational & $83.36(-0.80-306.92)$ & & & \\
\hline
\end{tabular}

${ }^{*} P<0.001$

\section{Discussion}

Despite the severe decline in European eel abundance over recent decades, little is known of how tide gates and other coastal infrastructure might impede their migration. In this study, escapement past tide gates in a small English stream was high (98.3\%), but delay was substantial when compared to an unimpeded control reach, with speed of migration past Gates 1 and 2 being 2.7 and 9.7 times slower, respectively. An orifice fish pass installed to increase fluvial connectivity through the gates was associated with decreased delay, even though eels were not observed to pass directly through it.

As few studies have attempted to quantify the impact of estuarine infrastructure on seaward migrating adult eels, there is limited opportunity to compare results. In one exception, high (100\%) escapement was observed for acoustic and PIT tagged silver eels that approached a complex of intertidal structures, which included tide gates, on the River Stour, UK (Piper et al. 2013). Further comparisons at present must be based on structures, such as undershot sluices at dams, which impose similar conditions to those encountered at the open top-hung tide gates of interest in this study, thus providing analogous scenarios. Based on the information available, efficiencies are highly variable. For example, on the River Ätran (Sweden), 15\% of radio tagged silver eels passed Ätrafors hydroelectric plant via bottom fed spill gates (Calles et al. 2010). Of interest, $74 \%$ of fish that eventually passed the dam via the turbines had first approached the spill gates, only to then reject this route of passage (see below discussion of avoidance behaviour). Conversely, at the Baigts hydroelectric facility in the Gave de Pau river (France), $76 \%$ of downstream moving radio and PIT tagged silver eels that explored alternate routes to the turbines (e.g. sluices, flap gates, and 
bypasses) subsequently passed via these structures (Travade et al. 2010). Travade et al. (2010) and others (e.g. Breteler et al. 2007; Jansen et al. 2007) suggest that eels tend to escape via the route of dominant flow, an observation supported by the current study in which most eels (75.9\%) exited through Gate 1 which discharged the highest volume.

Amphidromous behaviour has previously been observed for yellow eel, where mature adults migrate regularly between rivers and estuaries to feed (Thibault et al. 2007). Although a number of eels ( $n=$ 9) re-entered the River Stiffkey after initially passing through the gates, these individuals exhibited physiological features reflecting their preparedness for marine migration (Tesch 2003), and all eels subsequently passed downstream through the gates $\geq 15$ days prior to termination of the study without returning upstream.

Tide gates have previously been shown to delay actively seaward migrating species (Wright et al. 2014, for juvenile sea trout, Salmo trutta), but their influence on the downstream migration of adult European eel has not previously been reported. The role of behavioural avoidance is likely to be important in understanding the causes of delay at tide gates. While tide gates physically block migrating fish when closed, the narrow apertures through which water is discharged when open, and culvert entrances, may create a hydrodynamic barrier in the form of a rapid acceleration of flow which acts as a repellent (Pacific salmonid smolts: Enders et al. 2009; Kemp et al. 2005b, silver European eels: Piper et al. in prep.). Indeed, eels have been observed to exhibit non-passive exploratory behaviour at other riverine structures (silver American eels, Anguilla rostrata: Brown et al. 2009; Haro and Castro-Santos 2000, silver European eels: Behrmann-Godel and Eckmann 2003; Travade et al. 2010) during which they may reject an area approached, to either approach again, or find an alternative route (e.g. Brown et al. 2009). In this study, three key pieces of evidence suggest delay was at least in part a result of avoidance and exploration of conditions experienced at the tide gates. First, more than one third of eels (37.9\%) made more than one approach to the culverts, and a quarter (24.2\%) approached the area upstream of one gate prior to exiting through another. Second, a positive relationship was observed between mean degree of gate opening and speed of migration through the treatment reach, which was the second most significant relationship after light. Third, a negative relationship between the degree of gate opening at the time fish passed and duration of culvert passage suggests a behavioural element of avoidance contributing towards delay, although this could to some extent also be explained by lower water velocities within the culvert when the gate aperture was smaller. Avoidance may not have been solely induced by hydrodynamic stimuli. For example, continuous overhead cover, such as that associated with the culverts 
themselves, is also known to induce avoidance in other fish species (e.g. Kemp et al. 2005a for Pacific salmonids; Greenberg et al. 2012 for juvenile sea trout), indicating the potential for multiple factors associated with complex river infrastructure to have confounding influences.

The downstream migration of eels is commonly considered to be predominantly nocturnal (e.g. Aarestrup et al. 2008, 2010; Boubée and Williams 2006) and partially triggered by low temperatures (Vøllestad et al. 1986). In the present study, delay was elevated when temperatures were high, and eels passed the control reach and the gates only during periods of darkness. Greater delay was associated with increased light levels, suggesting that eels failing to pass the gates at night may have subsequently been inactive during the day (Davidsen et al. 2011).

Delayed migration could be detrimental. During the silvering process, the alimentary tract degenerates (Pankhurst and Sorensen 1984) and eels cease feeding (Olivereau and Olivereau 1997). Thus successful migration is based on efficient utilisation of finite energy reserves. Delay extends the migratory period, while avoidance and exploration uses energy that might be otherwise allocated to gamete development (Van den Thillart and Dufour 2009) or the 5000 to $6000 \mathrm{~km}$ oceanic migration to spawning grounds in the Sargasso Sea (Tesch 2003). The impact of delay, acting through increased energetic expense, may be exacerbated for those eels already compromised through infection with the invasive parasite Anguillicoloides crassus (Höglund et al. 1992) which may be present in up to $90 \%$ of the eel population in most European systems (Lefebvre and Crivelli 2004). Further, due to accumulation of fish delayed at structures, the potential for parasite disease transfer is also enhanced (Garcia de Leaniz 2008), as is the risk of predation by species such as cormorants, Phalacrocorax carbo, (Jepsen et al. 2010; Keller 1995) and otters, Lutra lutra, (Jenkins and Harper 1980) both of which are known to frequent the study site.

Delay was lower when the orifice was operational. Eels did not pass through the orifice, which was situated half way up the gate, supporting the results of other studies which report eels to be principally benthic oriented during freshwater migration (Jonsson 1991; Tesch 2003) exhibiting a preference for undershot pathways (Gosset et al. 2005; Russon and Kemp 2011a; Russon and Kemp 2011b). Reduced delay when the orifice was operational may have been due to the gates being open on more occasions when eels initially approached them, or the lower upstream salinity that may have resulted from the lower tides that occurred during these periods, as diadromous fish may need to adapt to abrupt salinity gradients (e.g. salmonid smolts: Otto 1971). However, there is currently little evidence to suggest eels suffer adverse physiological consequences in response to 
encountering stark transitions in salinity (Chan et al. 1967; Maetz and Skadhauge 1968; Rankin 2008).

This study demonstrated that, although tide gates did not impact escapement, migratory delay was considerable. This may be costly in terms of energetic expenditure and predation risk. Tide gates are common throughout the range of the European eel in regions where large areas of land have been reclaimed for agricultural and other anthropogenic purposes. Coastal infrastructure required to manage water levels will become increasingly important as sea levels and flood risk rise (Nicholls et al. 1999). Mitigation of the environmental impact of coastal infrastructure must be integrated as part of a wider design and planning process, which includes finding engineering solutions to protect migratory fish, such as the critically endangered European eel. Tide gate modifications designed to reduce migratory delay by increasing temporal longitudinal fluvial connectivity by opening wider for longer, whilst not compromising continued integrity of the tidal barrier, will provide a useful first step in the much needed development of sustainable infrastructure in the future.

\section{Acknowledgements}

This project was funded by the University of Southampton, the Environment Agency and the Interreg IVB Living North Sea Project. The authors thank Cefas, Wild Trout Trust, Buxton Conservation, Holkham Estate and Fishing Syndicate, Hull International Fisheries Institute, Aquatic Control Engineering, Norfolk EA Fisheries Team, Lady Kay Buxton, Rosie Edgington, Tom Harrison, Sam Sykes, Peter Carter, Simon Karlsson, Tom Worthington, Adam Piper, Peter Marchant, Ben Kerley, Josh Nightingale, Emma Dyson, Freddie Wells, Ralph Wright, Silvana Wright, Toby Diggens, Lee Corsi and Nick Stokes. 


\section{References}

Aarestrup, K., E.B. Thorstad, A. Koed, N. Jepsen, J.C. Svendsen, M.I. Pedersen, C. Skov, and F. Okland. 2008. Survival and behaviour of European silver eel in late freshwater and early marine phase during spring migration. Fisheries Management and Ecology 15: 435-440.

Aarestrup, K., E.B. Thorstad, A. Koed, J.C. Svendsen, N. Jepsen, M.I. Pedersen, and F. Okland. 2010. Survival and progression rates of large European silver eel Anguilla anguilla in late freshwater and early marine phases. Aquatic Biology 9: 263-270.

Baltazar-Soares, M., A. Biastoch, C. Harrod, R. Hanel, L. Marohn, E. Prigge, D. Evans, K. Bodles, E. Behrens, C.W. Boening, and C. Eizaguirre. 2014. Recruitment collapse and population structure of the European eel shaped by local ocean current dynamics. Current Biology 24: 104-108.

Behrmann-Godel, J., and R. Eckmann. 2003. A preliminary telemetry study of the migration of silver European eel (Anguilla anguilla L.) in the River Mosel, Germany. Ecology of Freshwater Fish 12: 196-202.

Berggren, T.J., and M.J. Filardo. 1993. An analysis of variable influencing the migration of juvenile salmonids in the Columbia River basin. North American Journal of Fisheries Management 13: 48-63.

Blaxter, J.H.S., and W. Dickson. 1959. Observations on swimming speeds of fish. J. Cons. - Cons. Perm. Int. Explor. Mer. 24: 472-479.

Boubée, J.A.T., and E.K. Williams. 2006. Downstream passage of silver eels at a small hydroelectric facility. Fisheries Management and Ecology 13: 165-176.

Boyd, C.E., and C.S. Tucker. 1998. Pond aquaculture water quality management. Boston: Kluwer Academic Publishers.

Boys, C.A., F.J. Kroon, T.M. Glasby, and K. Wilkinson. 2012. Improved fish and crustacean passage in tidal creeks following floodgate remediation. Journal of Applied Ecology 49: 223-233.

Breteler, J.K., T. Vriese, J. Borcherding, A. Breukelaar, L. Jorgensen, S. Staas, G. de Laak, and D. Ingendahl. 2007. Assessment of population size and migration routes of silver eel in the river Rhine based on a 2-year combined mark-recapture and telemetry study. ICES Journal of Marine Science 64: 1450-1456.

Brown, L., A. Haro, and T. Castro-Santos. 2009. Three-dimensional movement of silver-phase American eels in the forebay of a small hydroelectric facility. In Eels at the Edge: Science, Status and Conservation Concerns, ed. J.M. Casselman and D.K. Cairns, 277-291. Bethesda, Maryland: American Fisheries Society, Symposium 58.

Bruijs, M., and C. Durif. 2009. Silver eel migration and behaviour. In Spawning Migration of the European Eel, ed. G. Van den Thillart, S. Dufour and J.C. Rankin, 65-95. New York: Springer.

Bult, T.P., and W. Dekker. 2007. Experimental field study on the migratory behaviour of glass eels (Anguilla anguilla) at the interface of fresh and salt water. Ices Journal of Marine Science 64: 1396-1401.

Calles, O., S. Karlsson, P. Vezza, C. Comoglio, and J. Tielman. 2013. Success of a low-sloping rack for improving downstream passage of silver eels at a hydroelectric plant. Freshwater Biology 58: 2168-2179.

Calles, O., I.C. Olsson, C. Comoglio, P.S. Kemp, L. Blunden, M. Schmitz, and L.A. Greenberg. 2010. Size-dependent mortality of migratory silver eels at a hydropower plant, and implications for escapement to the sea. Freshwater Biology 55: 2167-2180.

Chan, D.K.O., I.C. Jones, I.W. Henderson, and J.C. Rankin. 1967. Studies on the experimental alteration of water and electrolyte composition of the eel Anguilla anguilla. Journal of Endocrinology 37: 297-317. 
Davidsen, J.G., B. Finstad, F. Okland, E.B. Thorstad, T.A. Mo, and A.H. Rikardsen. 2011. Early marine migration of European silver eel Anguilla anguilla in northern Norway. Journal of Fish Biology 78: 1390-1404.

Dekker, W. 2003. Did lack of spawners cause the collapse of the European eel, Anguilla anguilla? Fisheries Management and Ecology 10: 365-376.

Doehring, K., R.G. Young, J. Hay, and A.J. Quarterman. 2011. Suitability of Dual-frequency Identification Sonar (DIDSON) to monitor juvenile fish movement at floodgates. New Zealand Journal of Marine and Freshwater Research 45: 413-422.

EC. 2007. Council Regulation (EC) no 1100/2007 of 18 September 2007 establishing measures for the recovery of the stock of European eel. Official Journal of the European Union L248: 17-23.

Enders, E.C., M.H. Gessel, and J.G. Williams. 2009. Development of successful fish passage structures for downstream migrants requires knowledge of their behavioural response to accelerating flow. Canadian Journal of Fisheries and Aquatic Sciences 66: 2109-2117.

Feunteun, E. 2002. Management and restoration of European eel population (Anguilla anguilla): An impossible bargain. Ecological Engineering 18: 575-591.

Fofonoff, N.P., and R.C. Millard. 1983. Algorithms for computation of fundamental properties of seawater. In Unesco technical papers in marine science, 53.

Freyhof, J., and M. Kottelat. 2008. Anguilla anguilla. 2008 IUCN red list of threatened species. http://www.iucnredlist.org. Accessed 20 March 2011.

Friedland, K.D., M.J. Miller, and B. Knights. 2007. Oceanic changes in the Sargasso Sea and declines in recruitment of the European eel. Ices Journal of Marine Science 64: 519-530.

Garcia de Leaniz, C. 2008. Weir removal in salmonid streams: implications, challenges and practicalities. Hydrobiologia 609: 83-96.

Giannico, G., and J.A. Souder. 2005. Tide Gates in the Pacific Northwest: Operation, Types, and Environmental Effects. Oregon: Oregon State University.

Gosset, C., F. Travade, C. Durif, J. Rives, and P. Elie. 2005. Tests of two types of bypass for downstream migration of eels at a small hydroelectric power plant. River Research and Applications 21: 1095-1105.

Greenberg, L.A., O. Calles, J. Andersson, and T. Engqvist. 2012. Effect of trash diverters and overhead cover on downstream migrating brown trout smolts. Ecological Engineering 48: 25-29.

Haro, A., M. Odeh, J. Noreika, and T. Castro-Santos. 1998. Effect of water acceleration on downstream migratory behavior and passage of Atlantic salmon smolts and juvenile American shad at surface bypasses. Transactions of the American Fisheries Society 127: 118127.

Haro, A., and T. Castro-Santos. 2000. Behaviour and passage of silver-phase American eels, Anguilla rostrata (LeSueur), at a small hydroelectric facility. Dana 12: 33-42.

Harwell, M.R., E.N. Rubinstein, W.S. Hayes, and C.C. Olds. 1992. Summarizing Monte-Carlo results in methodological research - the 1-factor and 2-factor fixed effects ANOVA cases. Journal of Educational Statistics 17: 315-339.

Höglund, J., J. Andersson, and J. Hardig. 1992. Hematological responses in the European eel, Anguilla anguilla $\mathrm{L}$., to sublethal infestation by Anguillicola crassus in a thermal effluent of the Swedish Baltic. Journal of Fish Diseases 15: 507-514.

ICES. 2012. Report of the Joint EIFAAC/ICES Working Group on Eels (WGEEL), 3-9 September 2012, Copenhagen, Denmark, 824 pp. Copenhagen: ICES.

Jansen, H.M., H.V. Winter, M.C.M. Bruijs, and H.J.G. Polman. 2007. Just go with the flow? Route selection and mortality during downstream migration of silver eels in relation to river discharge. ICES Journal of Marine Science 64: 1437-1443.

Jenkins, D., and R.J. Harper. 1980. Ecology of otters in northern Scotland II. Analyses of otter (Lutra lutra) and mink (Mustela vision) faeces from Deeside, N.E Scotland in 1977-78. Journal of Animal Ecology 49: 737-754. 
Jepsen, N., R. Klenke, P. Sonnesen, and T. Bregnballe. 2010. The use of coded wire tags to estimate cormorant predation on fish stocks in an estuary. Marine and Freshwater Research 61: 320329.

Jonsson, N. 1991. Influence of water flow water temperature and light on fish migration in rivers. Nordic Journal of Freshwater Research: 20-35.

Keller, T. 1995. Food of cormorants Phalacrocorax carbo sinensis wintering in Bavaria, southern Germany. Ardea 83: 185-192.

Kemp, P.S., M.H. Gessel, and J.G. Williams. 2005a. Seaward migrating subyearling chinook salmon avoid overhead cover. Journal of Fish Biology 67: 1381-1391.

Kemp, P.S., M.H. Gessel, and J.G. Williams. 2005b. Fine-scale behavioral responses of Pacific salmonid smolts as they encounter divergence and acceleration of flow. Transactions of the American Fisheries Society 134: 390-398.

Knights, B. 1997. Risk assessment and management of contamination of eels (Anguilla spp.) by persistent xenobiotic organochlorine compounds. Chemistry and Ecology 13: 171-212.

Knights, B., and E.M. White. 1998. Enhancing immigration and recruitment of eels: The use of passes and associated trapping systems. Fisheries Management and Ecology 5: 459-471.

Laffaille, P., J.M. Caraguel, and A. Legault. 2007. Temporal patterns in the upstream migration of European glass eels (Anguilla anguilla) at the Couesnon estuarine dam. Estuarine Coastal and Shelf Science 73: 81-90.

Lefebvre, F.S., and A.J. Crivelli. 2004. Anguillicolosis: dynamics of the infection over two decades. Diseases of Aquatic Organisms 62: 227-232.

Lucas, M.C., D.H. Bubb, M. Jang, K. Ha, and J.E.G. Masters. 2009. Availability of and access to critical habitats in regulated rivers: effects of low-head barriers on threatened lampreys. Freshwater Biology 54: 621-634.

Maetz, J., and E. Skadhauge. 1968. Drinking rates and gill ionic turnover in relation to external salinities in the eel Anguilla anguilla. Nature 217: 371-373.

Moriarty, C., and W. Dekker. 1997. Management of European eel fisheries. Fisheries Bulletin 15: 1110.

Mouton, A.M., M. Stevens, T. Van den Neucker, D. Buysse, and J. Coeck. 2011. Adjusted barrier management to improve glass eel migration at an estuarine barrier. Marine EcologyProgress Series 439: 213-222.

Nicholls, R.J., F.M.J. Hoozemans, and M. Marchand. 1999. Increasing flood risk and wetland losses due to global sea-level rise: regional and global analyses. Global Environmental Change 9: S69-S87.

Olivereau, M., and J.M. Olivereau. 1997. Long-term starvation in the European eel: general effects and responses of pituitary growth hormone $(\mathrm{GH})$ and somatolactin $(\mathrm{SL})$ secreting cells. Fish Physiology and Biochemistry 17: 261-269.

Otto, R.G. 1971. Effects of salinity on survival and growth of pre-smolt coho salmon (Oncorhynchus kisutch). Journal of the Fisheries Research Board of Canada 28: 343-349.

Palstra, A., V. van Ginneken, and G. van den Thillart. 2008. Cost of transport and optimal swimming speed in farmed and wild European silver eels (Anguilla anguilla). Comparative Biochemistry and Physiology a-Molecular \& Integrative Physiology 151: 37-44.

Pankhurst, N.W., and P.W. Sorensen. 1984. Degeneration of the alimentary-tract in sexually maturing European Anguilla anguilla (L) and American eels Anguilla rostrata (Lesueur). Canadian Journal of Zoology-Revue Canadienne De Zoologie 62: 1143-1149.

Pawson, M. 2008. Anglian Rivers Sea Trout Project - Phase 1 Report, 72. Waterlooville: Wild Trout Trust.

Pedersen, M.I., N. Jepsen, K. Aarestrup, A. Koed, S. Pedersen, and F. Okland. 2012. Loss of European silver eel passing a hydropower station. Journal of Applied Ichthyology 28: 189-193.

Piper, A.T., R.M. Wright, and P.S. Kemp. 2012. The influence of attraction flow on upstream passage of European eel (Anguilla anguilla) at intertidal barriers. Ecological Engineering 44: 329-336. 
Piper, A.T., R.M. Wright, A.M. Walker, and P.S. Kemp. 2013. Escapement, route choice, barrier passage and entrainment of seaward migrating European eel, Anguilla anguilla, within a highly regulated lowland river. Ecological Engineering 57: 88-96.

Pollard, D.A., and J.C. Hannan. 1994. The ecological effects of structural flood mitigation works on fish habitats and fish communities in the lower Clarence River system of South-Eastern Australia. Estuaries 17: 427-461.

Rankin, J.C. 2008. Acclimation to seawater in the European eel Anguilla anguilla: Effects of silvering. In Spawning Migration of the European Eel, ed. G. Van den Thillart, S. Dufour and J.C.E. Rankin, 129-145. New York: Springer.

Robinet, T.T., and E.E. Feunteun. 2002. Sublethal effects of exposure to chemical compounds: A cause for the decline in Atlantic eels? Ecotoxicology 11: 265-277.

Roni, P., T.J. Beechie, R.E. Bilby, F.E. Leonetti, M.M. Pollock, and G.R. Pess. 2002. A review of stream restoration techniques and a hierarchical strategy for prioritizing restoration in Pacific northwest watersheds. North American Journal of Fisheries Management 22: 1-20.

Russell, I.C., A. Moore, S. Ives, L.T. Kell, M.J. Ives, and R.O. Stonehewer. 1998. The migratory behaviour of juvenile and adult salmonids in relation to an estuarine barrage. Hydrobiologia 371-372: 321-333.

Russon, I.J., and P.S. Kemp. 2011a. Advancing provision of multi-species fish passage: Behaviour of adult European eel (Anguilla anguilla) and brown trout (Salmo trutta) in response to accelerating flow. Ecological Engineering 37: 2018-2024.

Russon, I.J., and P.S. Kemp. 2011b. Experimental quantification of the swimming performance and behaviour of spawning run river lamprey Lampetra fluviatilis and European eel Anguilla anguilla. Journal of Fish Biology 78: 1965-1975.

Russon, I.J., P.S. Kemp, and O. Calles. 2010. Response of downstream migrating adult European eels (Anguilla anguilla) to bar racks under experimental conditions. Ecology of Freshwater Fish 19: 197-205.

Tesch, F.W. 2003. The Eel. Oxford: Blackwell Science.

Thibault, I., J.J. Dodson, and F. Caron. 2007. Yellow-stage American eel movements determined by microtagging and acoustic telemetry in the St Jean River watershed, Gaspe, Quebec, Canada. Journal of Fish Biology 71: 1095-1112.

Travade, F., M. Larinier, S. Subra, P. Gomes, and E. De-Oliveira. 2010. Behaviour and passage of European silver eels (Anguilla anguilla) at a small hydropower plant during their downstream migration. Knowledge and Management of Aquatic Ecosystems 398: 1-19.

Van den Thillart, G., and S. Dufour. 2009. How to estimate the reproductive success of European silver eels. In Spawning Migration of the European Eel, Fish and Fisheries, ed. G. Van den Thillart, S. Dufour and J.C. Rankin, 3-13: Springer.

Vøllestad, L.A., B. Jonsson, N.A. Hvidsten, T.F. Naesje, O. Haraldstad, and J. Ruudhansen. 1986. Environmental factors regulating the seaward migration of European silver eels (Anguilla anguilla). Canadian Journal of Fisheries and Aquatic Sciences 43: 1909-1916.

Winter, H.V., H.M. Jansen, and M.C.M. Bruijs. 2006. Assessing the impact of hydropower and fisheries on downstream migrating silver eel, Anguilla anguilla, by telemetry in the River Meuse. Ecology of Freshwater Fish 15: 221-228.

Wright, G.V., R.M. Wright, and P.S. Kemp. 2014. Impact of tide gates on the migration of juvenile sea trout, Salmo trutta. Ecological Engineering 71: 615-622.

Zaugg, W.S., E.F. Prentice, and F.W. Waknitz. 1985. Importance of river migration to the development of seawater tolerance in Columbia River anadromous salmonids. Aquaculture 51: 33-47. 